\title{
ANALISIS NILAI-NILAI TOLERANSI DALAM BUKU "SENANG BELAJAR AGAMA ISLAM DAN BUDI PEKERTI" DI KELAS IV DAN V SD DI KAB. KARANGANYAR
}

\author{
Rizky Martha Oktavia \\ Pascasarjana, IAIN Surakarta \\ rizkymarthaoktavia@gmail.com \\ Fauzi Muharom \\ IAIN Surakarta \\ Fauzi.muharom@iain-surakarta.ac.id
}

\begin{abstract}
The success of tolerance education through Islamic religious education can be supported by components of teaching materials, for example the book "Happy to Learn Islam and Morals" for Grade IV and V Elementary School Students in Kab. Karanganyar. The problem is, how is the analysis of tolerance values in the book? The purpose of the study, namely to analyze the values of tolerance in the book "Happy to Learn Islam and Morals" for Grade IV and V Elementary School Students in Kab. Karanganyar. With a qualitative approach and the type of literature research, research data in the form of tolerance values obtained from book data sources were collected by documentation studies. Its validity is checked by techniques (1) triangulation, (2) member checking, (3) increasing diligence, and (4) material adequacy. Based on the results of the content analysis, it was found that tolerance values were 31 values of tolerance, for example (1) not laughing at the way of worshiping other religions, (2) not discussing the shortcomings of other religions, (3) not criticizing the rules of worship of other religious people. Suggestions to the author of the Islamic Religious Education (PAI) SD book, namely the need to spread the value of tolerance in each chapter; PAI teachers and fourth and fifth grade elementary school students need to read, even trace the value of tolerance so that they can be taught sustainably; fourth and fifth grade elementary school students need to read and apply the value of tolerance in books in consultation with their parents and teachers; elementary school principals can use the distribution of tolerance values as a guide for choosing, determining, and designing social activities in schools to train students' sensitivity to become a tolerant generation.
\end{abstract}

Keywords: the value of tolerance, character, Islamic religious education

\section{Abstrak}

Kesuksesan pendidikan toleransi melalui pendidikan agama Islam dapat ditopang oleh komponen bahan ajar, misalnya buku "Senang Belajar Agama Islam dan Budi Pekerti" bagi Siswa Kelas IV dan V SD di Kab. Karanganyar. Permasalahannya, bagaimana analisis nilai-nilai toleransi 
dalam buku tersebut? Tujuan penelitian, yaitu menganalisis nilai-nilai toleransi dalam buku "Senang Belajar Agama Islam dan Budi Pekerti" bagi Siswa Kelas IV dan V SD di Kab. Karanganyar. Dengan pendekatan kualitatif dan jenis penelitian pustaka, data penelitian berupa nilai-nilai toleransi diperoleh dari sumber data buku dikumpulkan dengan studi dokumentasi. Keabsahannya diperiksa dengan teknik (1) triangulasi, (2) pengecekan anggota, (3) meningkatkan ketekunan, dan (4) kecukupan bahan. Berdasarkan hasil analisis isi ditemukan nilai-nilai toleransi, yakni 31 nilai toleransi, misalnya (1) tidak menertawakan cara beribadah umat beragama lain, (2) tidak membicarakan kekurangan agama umat beragama lain, (3) tidak mencela aturan beribadah umat beragama lain. Saran kepada penulis buku Pendidikan Agama Islam (PAI) SD, yakni perlu penyebaran nilai toleransi pada setiap bab; guru PAI dan siswa kelas IV dan V SD perlu membaca, bahkan menelusuri nilai toleransi agar dapat diajarkan berkelanjutan; siswa kelas IV dan V SD perlu membaca dan menerapkan nilai toleransi dalam buku dengan berkonsultasi pada orang tua dan guru yang membinanya; kepala SD dapat menjadikan sebaran nilai-nilai toleransi sebagai panduan untuk memilih, menentukan, dan merancang kegiataan sosial kemasyarakatan di sekolah untuk melatih kepekaan siswa menjadi generasi yang toleran. Kata-kata Kunci: nilai toleransi, budi pekerti, pendidikan
agama Islam

\section{PENDAHULUAN}

Warga masyarakat di lingkungan multikultur biasa bertemu dengan perbedaan. Selanjutnya, mereka saling menghormati dan menghargai antarsesama. Pada praktiknya, orang tua harus tetap waspada terhadap kemungkinan tumbuhnya intoleransi yang dialami oleh anak-anak pada usia dini. Perilaku itu berbahaya karena menimbulkan kekurangnyamanan dan ketidakharmonisan hidup anak-anak. Sebagai gambaran, sesama anak usia sekolah dasar kadang sudah terbiasa dalam interaksi sehari-hari. Mereka bermain dan bersenda gurau tanpa ada pihak yang terganggu. Karena terpengaruh oleh intoleransi melalui media massa, perilaku mengganggu sesama teman seolah biasa meskipun sekadar menyembunyikan permainan kawan; mengejek sesama kawan; mengolok-olok keterbatasan diri kawan; bahkan menyakiti hati sesamanya dengan ujaran kebencian.

Jika terabaikan, bukan toleransi yang terbentuk di masyarakat multikultur. Sebaliknya, mereka justru terpapar oleh intoleransi terhadap teman sejawatnya, seolah tidak menghargai orang lain, tidak memahami 
agama, tidak menghargai nilai-nilai dan budaya masyarakat ${ }^{1}$. Pada konteks fluktuatif situasi itu, saat berlangsung pendidikan informal, orang tua dan guru semestinya bekerjasama untuk mendidik putra-putrinya. Akan tetapi, seiring dengan maraknya budaya persekolahan, pembentukan watak anak kerap diserahkan ke guru pelajaran PAI. Akibatnya, guru menanggung beban tanggung jawab yang berat karena ada tuntutan untuk menyiapkan pendidikan yang profesional, termasuk menciptakan pembelajaran yang berkarakter misalnya bertoleransi, bereligius, bermoral, dan beretika di sekolah dan berbudaya di masyarakat ${ }^{2}$.

Untuk itu, materi toleransi dalam PAI sudah sepatutnya diberikan ke anak-anak sejak dini, masa usia PAUD. Bila terabaikan, lenyaphilangnya toleransi sungguh berbahaya ${ }^{3}$. Terkait dengan itu, kedekatan orang tua turut menentukan masa depan anak. Mereka harus memedulikannya. Pada kenyataannya, ketergantungan anak pada lingkungan sosial keluarga sangat dominan sehingga dalam mendidik anak, kerjasama orang tua dan guru perlu diwujudkan ${ }^{4}$. Seterusnya, materi PAI perlu dipersiapkan dan diberikan pada saat anak menempuh pendidikan dasar, SD-SMP. Pada saat itu, ketergantungan anak kepada lingkungan sosial masyarakat makin meluas. anak SD kelas tinggi, misalnya, kelas IV dan V mulai memiliki jaringan kemasyarakatan yang makin masif.

Dari kondisi ini, persahabatan mereka perlu dibentengi dengan kebenaran dan kebiasaan berperilaku, misalnya tentang kelaziman menghargai antarteman yang berbeda, baik berbeda budaya maupun keyakinan beragama. Boleh jadi, ada sesama siswa SD yang berbeda suku

${ }^{1}$ Triwiyanto Teguh, Gelombang Liberalisme Pendidikan: Mengawal Tata Kelola Pendidikan untuk Rakyat, (Jakarta: PT Kompas Media Nusantara, 2019),h.14

Sedarmayanti, dkk, Membangun dan Mengembangkan Human Capital Unggul melalui Pendidikan, Kinerja, dan Produktivitas Kerja di Era 4.0, (Bandung: PT Refika Aditama, 2020),h.6

${ }^{2}$ Muhaimin, Pengembangan Kurikulum Pendidikan Agama Islam di Sekolah, Madrasah, dan Perguruan Tinggi, (Jakarta: PT Raja Grafindo Persada, 2005),h.55

Agung S., Leo, Pendidikan Karakter sebagai Fondasi Keterampilan Abad 21 (5CS Super Skills), (UNS : Pidato Pengukuhan Guru Besar Bidang Ilmu Pendidikan 5 November, 2019), h.32

3 Atmanto Nugroho Eko. SIKAP TOLERANSI SISWA MADRASAH(Pandangan Siswa Madrasah Aliyah Negeri 1 Kendal terhadap Toleransi Antar Umat Beragama).https://simlitbangdiklat.kemenag.go.id

/simlitbang/spdata/upload/dokumenpenelitian/1557990953Exsum_Penelitian_Toleran si_SMA.pdf. diunduh 28 Januari 2020, pukul 19.30 WIB.

${ }^{4}$ Mahya Itaf Bareeq, Mendidik Anak ala Rasulullah sejak dalam Kandungan sampai Usia 18 Tahun., (Klaten: Abata Press, 2014),h.107 
karena orang tua bermigrasi; serta ada segenap siswa SD yang berbeda agama karena orang tua berbeda profesi. Pendek kata, di lingkungan yang begitu kompleksitasnya, peserta didik usia pendidikan dasar yang beragama Islam harus dibekali wawasan toleransi yang tepat dan benar. Jika tidak diperhatikan dengan benar, intoleransi dan radikalisme melonjak di persekolahan negeri dan/atau swasta ${ }^{5}$. Dalam rangka mengantisipasi hal itu, muatan toleransi dalam pembelajaran PAI perlu diwujudkan seoptimal mungkin.

Untuk membentuk peserta didik usia pendidikan dasar yang menguasai PAI secara maksimal, upaya formal dilakukan oleh berbagai pihak, termasuk pihak sekolah. Hal itu direalisasikan dengan penyediaan tempat ibadah, guru PAI di sekolah, serta referensi PAI, bahkan motivasi kepada para peserta didik agar memanfaatkan kesempatan belajar di rumah, terutama untuk menerapkan kehidupan beragama Islam dengan tekun dan benar. Seiring dengan itu, pihak sekolah memotivasi peserta didik untuk belajar PAI melalui buku yang relevan dengan kurikulum yang digunakan di sekolah dasar. Secara praktis, ketersediaan tempat ibadah dan kesiapan guru PAI sudah relatif memenuhi kebutuhan. Akan tetapi, ada substansi buku yang masih belum terungkap, yakni hal menumbuhkan jiwa toleransi ${ }^{6}$.

Untuk itu, sudah sepatutnya bila hal toleransi dalam buku PAI mendapatkan perhatian serius karena eksistensi dan aktualisasinya berkenaan langsung dengan praktik toleransi yang fluktuatif dalam kehidupan sosial sehari-hari. Berkenaan dengan itu, Rusydiyah berpendapat bahwa tatanan sosial dalam Islam adalah sebuah kesatuan sehingga memiliki tujuan untuk kepentingan kemaslahatan umat manusia, bukan hanya atas dasar kepentingan golongan, ras, dan etnis, serta kelompok tertentu ${ }^{7}$. Oleh sebab itu, toleransi terhadap sesama perlu dan penting dididikkan dengan benar. Begitu pentingnya aspek toleransi yang harus ditanamkan kepada peserta didik sejak dini, guru PAI yang tergabung dalam KKG PAI di Kab. Karanganyar bermusyarah dan bermufakat menggunakan buku tersebut.

Ironisnya, peneliti belum pernah mendengar, melihat, dan membaca laporan hasil penelitian tentang toleransi yang terkandung dalam buku tersebut. Padahal, seperti lazimnya, kelembagaan Kementerian

5 Dja'far Alamsyah M, Intoleransi! Memahami Kebencian dan Kekerasan atas Nama Agama, (Jakarta: PT Elex Media Komputindo, 2018),h.211-212

${ }^{6}$ Sholeh, M. Asrorun Ni'am. dan Humaidi, Lutfi, Panduan Sekolah \& Madrasah Ramah Anak, (Jakarta: Penerbit Erlangga, 2016),h.181

${ }^{7}$ Rusydiyah Evi Fatimatur, Aliran dan Paradigma Pemikiran Pendidikan Agama Islam Kontemporer, (Surabaya: UIN Sunan Ampel Press,2019),h.20 
Pendidikan dan Kebudayaan Republik Indonesia (2014) menetapkan keberlakuan Kurikulum 2013 tentang pelajaran PAI di kelas IV dan V SD. Departemen Agama menegaskan pentingnya rasa persatuan antarwarga yang dibangun dari lembaga pendidikan dasar, seperti tertuang dalam pernyataan, "Peran nyata Kementerian Agama dalam mencegah radikalisme, intoleransi dan terorisme dapat terlihat jelas pada Visi, Misi dan Program Kerja yang dilakukan oleh Kementerian Agama selama ini.

Kementerian Agama yang membawahi ponpes, ormas keagamaan, madrasah, tenaga kependidikan, anak didik, serta masyarakat senantiasa membimbing pada konsep kebangsaan dan pemahaman keagamaan yang sesuai dengan pendiri bangsa dahulu", ucap Musta'in ${ }^{8}$.

Berkenaan dengan substansi toleransi buku PAI, banyak kajian empiris penelitian, misalnya oleh Muhamad Furqon dalam Tesis yang berjudul "Analisis Nilai-Nilai Toleransi dalam Buku Teks Mata PAI dan Budi Pekerti Tingkat SMA Terbitan Kemendikbud Tahun 2017. Hasil analisis isi secara deskriptif menunjukkan bahwa materi pokok di dalam buku teks PAI dan Budi Pekerti tingkat SMA secara implisit/eksplisit mengandung nilai toleransi 20 bab dari total 33 bab keseluruhannya. Ada bab khusus membahas tema toleransi di kelas X. Di dalam buku PAI dan Budi Pekerti tingkat SMA banyak bermuatan nilai-nilai toleransi, 28 teks. Adapun nilai-nilai toleransi, yaitu menekankan pentingnya menjaga kedamaian/keamanan kehidupan bermasyarakat; mengusung persatuan; mengedepankan saling menghormati; mengutamakan musyawarah mencapai mufakat; menekankan toleransi berdakwah; dan adanya kebebasan berpendapat.

Sepola dengan itu, penelitian tentang substansi toleransi dilakukan Azhar Rahmanto dalam Tesis berjudul "Nilai Toleransi dalam Buku Akidah Akhlak dan Implementasinya pada Pembelajaran di SMA Muhammadiyah Bantul ${ }^{9}$. Berdasarkan hasil analisis data dengan metode deskriptif analitik menunjukkan bahwa terdapat nilai-nilai toleransi dalam buku akidah akhlak kelas X dan XI SMA di SMA Muhammadiyah Bantul seperti gotong royong, kerjasama, toleran, damai, santun, responsif, dan proaktif dalam menyelesaikan permasalahan, serta menghormati, saling memaafkan, selalu berbuat baik dalam bermuamalah, saling memberikan manfaat kepada orang lain. Bentuk implementasi nilai-nilai toleransi di

${ }^{8}$ Ahmad. Musta'in. (2017). Peran Kemenag Dalam Pencegahan Radikalisme, Intoleransi \& Terorisme.http://karanganyar.kemenag.go.id/ berita/read/-perankemenag-dalam- pencegahan-radikalisme-intoleransi-terorisme.

9 Rahmanto A., Nilai Toleransi Beragama dalam Buku Akidah Akhlak dan Implementasinya pada Pembelajaran di SMA Muhammadiyah Satu Bantul Yogyakarta. Tesis, 2019. (https://digilib.uin-suka.ac.id/id/eprint/39029/). 
dalam materi pada buku dalam pembelajaran akidah akhlak di SMA Muhammadiyah Bantul dapat dilihat dalam RPP yang mengandung nilai toleransi.

Toleransi beragama tidak hanya pada mata pelajaran pendidikan kewarganegaraan, tetapi juga tersaji pada Kurikulum 2016 Pendidikan Agama. Ini tercantum pada penelitian Mujahidil Mustaqim. Pentingnya aspek substansi toleransi dalam PAI diungkapkan oleh pengawas sekolah, yakni Sri Mawarti dalam artikel Nilai-Nilai Pendidikan Toleransi dalam PAI. Dalam artikel itu diungkapkan, "Toleransi merupakan sikap menghargai perbedaan dan kerjasama untuk mencapai cita-cita mulia dalam bingkai keberagaman ${ }^{10}$. Dalam PAI, toleransi tercermin pada 4 isu pokok sebagai dasar pendidikan toleransi, yaitu kesatuan dalam aspek ke-Tuhan-an dan pesan-Nya; kesatuan kenabian; tidak ada paksaan dalam beragama; dan pengakuan terhadap eksistensi agama lain. Namun, dalam PAI diperoleh gambaran bahwa implementasi PAI, jika dilihat dari segi materi dalam buku ajar Al-Qur'an Hadits dan Fiqih, belum sepenuhnya mencerminkan visi toleransi"'

Berdasarkan kajian empiris tentang pentingnya aspek toleransi di dunia Pendidikan, PAI berperan penting dalam membentuk karakter peserta didik sehingga benar-benar mengacu pada toleransi yang ditegaskan dalam Al-Qur'an dan Hadist. Butir-butir toleransi perlu diperhatikan dan menjadi bahan pertimbangan dalam pembuatan bahan ajar PAI di semua jenjang Pendidikan. Berdasarkan pertimbangan pentingnya butir-butir toleransi di dalam bahan ajar, maka menarik untuk menganalisis buku "Senang Belajar Agama Islam dan Budi Pekerti" bagi Siswa Kelas IV dan V SD di Kab. Karanganyar. Buku itu merupakan satu-satunya buku pelajaran PAI yang digunakan di Kab. Karanganyar. Buku itu dipilih oleh komunitas KKG PAI SD, tetapi belum ditelaah secara lengkap. Padahal, setiap bab berisi kompetensi inti, kompetensi dasar, tujuan pembelajaran, proses pembelajaran, penilaian, pengayaan, dan remedial, serta interaksi dengan orang tua. Akan tetapi, misalnya berkaitan dengan aspek toleransi, kompetensinya disusun tidak berurutan sesuai kompetensi dasar.

Selain itu, ada kasus intoleransi di Kab. Karanganyar, yakni sekolah tidak mengadakan upacara bendera. Kejadian ini menjadi sorotan nasional dan menandai adanya sikap intoleransi di Kab. Karanganyar, meski akhirnya, sekolah mengubah sikap dengan bersedia mengadakan upacara bendera. Untuk menguatkan sikap toleransi di Kab. Karanganyar,

10 Mawarti Sri, Nilai-Nilai Pendidikan Toleransi Dalam Pembelajaran Agama Islam. (Pekanbaru: puslit.Ippm@uin-suska.ac.id,2017)

11 Ibid, Nilai-Nilai Pendidikan Toleransi Dalam Pembelajaran Agama Islam. (Pekanbaru:.Ippm@uin-suska.ac.id,2017 
Kementerian Agama pernah memberikan penegasan pentingnya toleransi dengan pernyataan sebagai berikut. "Peran Kementerian Agama dalam mencegah radikalisme, intoleransi dan terorisme terlihat pada Visi, Misi dan Program Kerja Kementerian Agama. Dalam setiap kesempatannya, Kementerian Agama yang membawahi ponpes, ormas keagamaan, madrasah, tenaga kependidikan, anak didik, serta masyarakat senantiasa membimbing pada konsep kebangsaan dan pemahaman keagamaan yang sesuai dengan pendiri bangsa dahulu”, ucap Musta'in ${ }^{12}$. Selaras dengan pernyataan kepala Kantor Kementerian Agama Kab. Karanganyar ini, menganalisis buku "Senang Belajar Agama Islam dan Budi Pekerti" dari aspek toleransi perlu dilakukan.

\section{Metode Penelitian}

Penelitian "Analisis Nilai-nilai Toleransi dalam Buku 'Senang Belajar Agama Islam dan Budi Pekerti' bagi Siswa Kelas IV dan V SD di Kab. Karanganyar" ini merupakan penelitian pustaka berpendekatan kualitatif. Jenis penelitian itu digunakan karena tidak diberikan perlakuan terhadap objek penelitian, yakni nilai-nilai tolerasi dalam buku sebagai sumber data; sebatas mendeskripsikan nilai-nilai tolerasi secara otentik, tanpa menambah atau menguranginya, sesuai dengan fakta data dalam sumber data; bersifat deskriptif-kualitatif. Dalam hal ini, Drew, Hardman, dan Hosp bahwa data berupa substansi toleransi dalam bahasa pengarang buku $^{13}$. Artinya, peneliti mendeskripsikan objek sesuai dengan fenomena nilai toleransi, lalu mendeskripsikan dengan kata-kata, bukan operasionalisasi angka matematis. Jadi, melalui penelitian kualitatif ini dihasilkan deskripsi data toleransi apa adanya.

Penelitian ini dilaksanakan di lingkungan perpustakaan sebagai teknik penelitian dengan pengumpulan data. Kepustakaan dimaksud berupa buku pelajaran yang memiliki relevansi dengan data penelitian. Dalam hal ini, peneliti menjadikan kepustakaan sebagai "ruang atau tempat" penelitian berlangsung. Untuk itu, peneliti meneliti (1) buku pelajaran agama Islam, termasuk pengangan guru bagi siswa kelas IV dan V SD/MI; (2) kurikulum 2013 yang direvisi; serta (3) referensi pendukung berkenaan dengan substansi penelitian. Dengan demikian, peneliti tidak ke lapangan, namun lebih terfokus pada isi buku terpilih

12 Ahmad. Musta'in. (2017). Peran Kemenag Dalam Pencegahan Radikalisme,

Intoleransi \&.http://karanganyar.kemenag.go.id/berita/read/-peran-kemenag-dalampencegahan-radikalisme-intoleransi-terorisme.

${ }^{13}$ Drew, Clifford J.Hardman, Michael L dan Hosp, Jonh L, Penelitian Pendidikan: Merancang dan Melaksanakan Penelitian pada Bidang Pendidikan, (Jakarta: PT. Indeks,2017),h. 266 
yang telah tersedia di perpustakaan, baik perpustakaan, umum, perpustakaan sekolah, maupun perpustakaan pribadi. Dengan begitu, peneliti menggunakan multiinformasi yang tersedia dalam pustaka yang ditetapkan $^{14}$.

Data nilai-nilai toleransi Buku "Senang Belajar Agama Islam dan Budi Pekerti” bagi Siswa Kelas IV dan V SD di Kab. Karanganyar, sebagai sumber data primer. Khusus buku kelas IV terdiri atas $14 \mathrm{Bab}$ (160) halaman. Sementara itu, buku kelas V memiliki ukuran dan kriteria yang sama. Secara singkat dapat dijelaskan karakteristik sumber data primer, yaitu dikarang Moh. Masrun S., Musafak, Suradi, dan Choeroni; diterbitkan Penerbit Erlangga; khusus kelas IV dan V SD/MI; disusun berdasarkan kompetensi inti dan dasar, Kurikulum 2013 revisi (Permendikbud No. 24 2016) berorientasi kecakapan hidup; diutamakan unsur keimanan, ibadah, Alquran, dan Tarikh Akhlak. Sementara itu, sumber data sekunder berupa naskah-naskah ilmiah, yakni artikel, tesis, dan buku, serta peraturan-peraturan yang berkaitan dengan masalah penelitian.

Pengumpulan data dengan teknik studi dokumentasi untuk mendapatkan data tentang nilai toleransi yang terkandung dalam dokumen Buku "Senang Belajar Agama Islam dan Budi Pekerti"bagi Siswa Kelas IV dan V SD yang digunakan di Kab. Karanganyar. Langkah itu dilakukan berulang hingga data dimaksud ditemukan komprehensif. Apalagi, data yang diperlukan berada dalam dokumen tercetak secara resmi sehingga keberadaannya sudah terbakukan sistematis. Keabsahan data dalam penelitian ini diperiksa dengan teknik (1) triangulasi, (2) pengecekan anggota, (3) meningkatkan ketekunan, dan (4) kecukupan bahan ${ }^{15}$.

Teknik triangulasi dilakukan dengan triangulasi sumber. Artinya, data nilai-nilai toleransi dikonfirmasi kembali menggunakan sumber yang berbeda, yakni berupa sumber-sumber sekunder tentang nilai toleransi. Seiring dengan itu, pengecekan keabsahan data dilakukan dengan pengecekan anggota. Artinya, data penelitian akan ditunjukkan kepada anggota KKG guru pendidikan agama Islam di jenjang SD/MI di lingkungan peneliti bertugas. Sehubungan dengan itu, peningkatan ketekunan untuk memeriksa keabsahan data juga peneliti lakukan dengan cermat agar terhindar dari kesalahan. Senada dengan proses itu, pemeriksaan keabsahan data dilakukan dengan teknik kecukupan data di

${ }^{14}$ Ratna Nyoman Kutha, Metodologi Penelitian: Kajian Budaya dan Ilmu Sosial Humaniora pada Umumnya, (Yogyakarta: Pustaka Pelajar,2010),h. 200

${ }^{15}$ Ulfatin N, Metode Penelitian Kualitatif di Bidang Pendidikan: Teori dan Aplikasinya,(Malang: Media Nusa Creative,2015),h. 270-275 
lapangan. Artinya, pengecekan keabsahan data juga dilakukan dengan mencukupkan sumber sekunder, termasuk buku berisi pengertian dan nilai toleransi.

Data dianalisis menggunakan metode analisis isi karena peneliti menelaah catatan dokumen sebagai sumber data. Untuk itu, peneliti mengode setiap nilai toleransi dalam buku. Secara praktis, nilai toleransi tampak dalam bentuk kata, frase, kalimat, serta gambar sebagai perilaku anak dalam kehidupan sehari-hari. Nilai-nilai toleransi dalam buku tersebut, dalam bahasa penulis buku, menjadi bagian teks. Pola kerja analisis isi mengikuti pemikiran Bungin ${ }^{16}$, yakni mengidentifikasi pertanyaan penelitian, menentukan kategori analitik, membaca data dan menetapkan kategori data, menetapkan kriteria seleksi potongan data, memilah-milah data, mendeskripsikan data, dan memberikan penjelasan terhadap data tiap temuan ${ }^{17}$. Langkah menemukan data berkenaan dengan mengidentifikasi pertanyaan penelitian; langkah mengklasifikasi data berkenaan dengan menentukan kategori analitik, membaca data, menentapkan kriteria, dan memilah data; langkah prediksi dan pemaparan data berkenaan dengan pendeskripsian dan penjelasan data.

\section{PEMBAHASAN}

Sebaran nilai toleransi dalam buku PAI kelas IV dan V dapat dibentangkan pada Grafik 1 berikut.

\section{Grafik 1. Gambaran Toleransi dalam Buku Pendidikan Agama Islam Kelas IV dan V SD}

\footnotetext{
${ }^{16}$ Bungin M. Burhan, Penelitian Kualitatif: Komunikasi, Ekonomi, Kebijakan Publik, dan Ilmu Sosial Lainnya. (Jakarta: Kencana Prenada Media Group,2009),h.159

${ }^{17} \mathrm{Ibid}$, Metode Penelitian Kualitatif di Bidang Pendidikan: Teori dan Aplikasinya,(Malang:

Media Nusa Creative,2015),h.237-238
} 


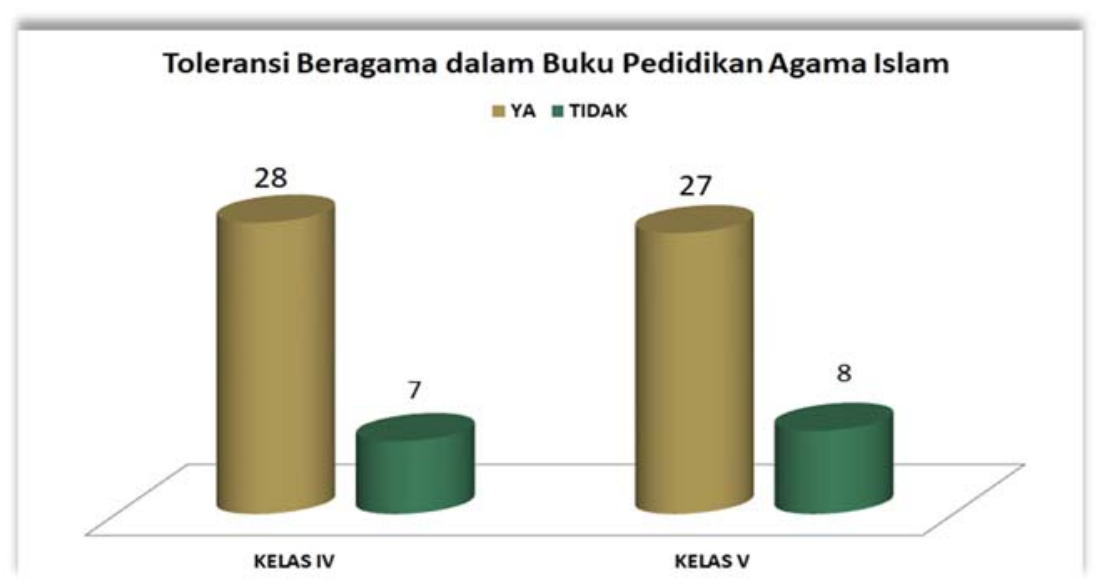

Bertolak dari Grafik 1., terdapat 35 nilai toleransi yang peneliti himpun. Dari 35 nilai toleransi itu ada sebaran 28 nilai di buku kelas IV dan 27 butir di buku kelas V. Sementara itu, terdapat 7 nilai toleransi yang tidak terdapat di kelas IV dan 8 nilai yang tidak terdapat dalam buku kelas V SD. Data itu menunjukkan bahwa penulis buku dapat memilih nilai-nilai dari beragam sumber, lalu menempatkannya sesuai dengan kreativitas masing-masing dengan mengacu pada Kurikulum 2013. Posisi nilai-nilai toleransi tersebut khas pada buku itu. Artinya, sebaran nilai toleransi tidak selalu pada bab tertentu, tetapi memungkinkan muncul pada bab yang berbeda.

Berdasarkan data itu, penjelasan secara eksplanatif tentang nilainilai toleransi pada Buku Kelas IV diuraikan berikut. Nilai tidak menertawakan cara beribadah umat beragama lain, tergambarkan dalam ungkapan contoh "Santun dan menghargai teman di masyarakat. Di antara nilai bersikap santun dan menghargai teman adalah sikap saling menghargai, menghormati, dan menyayangi. Tersirat di dalamnya setiap individu perlu bersopan santun terhadap sesama, termasuk menghormati orang lain beribadah. Untuk itu, nilai tidak membicarakan kekurangan agama umat beragama lain diperlukan. Namun, hal itu hendaknya muncul dari pribadi seseorang, bukan tekanan dari luar. Dalam buku kelas IV tercantum pernyataan ini, "sikap menghormati adalah sikap saling menghargai yang muncul dari dalam diri sendiri yang ditujukan pada orang lain.

Dengan toleransi itu, umat Islam memiliki nilai toleransi tidak mencela aturan beribadah umat beragama lain. Hal itu diungkapkan dengan tidak membicarakan kejelekan teman lain dan santun adalah sikap seseorang saling menghargai antarsesama, tidak sombang, dan tidak angkuh. Terkait dengan itu, toleransi dapat dilakukan dengan tidak 
membandingkan agama yang dianut dengan agama lain. Hal itu tersirat dalam contoh, tidak membicarakan hal-hal yang dilarang agama, serta ketika bergaul dengan siswa, kita harus bersikap santun dan menghargai mereka. Sikap toleransi ditampakkan dengan tidak mencela aturan beribadah umat beragama lain. Secara tegas, seseorang perlu bertoleransi, yakni jangan pernah merasa diri paling benar. Dengan bertoleransi, yakni tidak menghalangi orang menunaikan agama sesuai dengan waktunya tidak akan terjadi. Seperti terungkap bahwa aqidah Islam yang menguasai jiwa akan membuahkan keutaman kemanusiaan yang tinggi, seperti pemberani dalam kebenaran dan pantang menyerah, termasuk tidak merasa paling benar.

Untuk menempatkan jiwa yang tidak selalu merasa paling benar, nilai tidak melarang orang bersilaturahim saat hari besar agama tertentu perlu dikembangkan dalam kehidupan sosial yang beragam latar belakang. Dengan begitu, ada pengamalan salah satu isi pokok kandung surah Al-Fill adalah, yakni sifat iri dapat menyebabkan kehancuran. Secara hati-hati dalam bermasyarakat, umat Islam menegakkan nilai toleransi, yakni tidak berisik bila sedang berlangsung ibadah di lingkungan tertentu, termasuk berperilaku iman kepada rasul dapat diwujudkan dengan meneladani ketaatan rasul kepada Allah dan sifat terpuji mereka yang gemar menyambung silaturahim. Bila dikembangkan, umat Islam telah melaksanakan toleransi, tidak menyinggung agama seseorang saat berdebat tentang suatu masalah.

Hal itu dapat dilakukan apabila mengobrol, seseorang yang sedang berada dalam perbedaan pendapat, hargailah pendapat temanmu. Bila ada perbedaan persepsi, perlu diingat nilai tidak menutup pintu maaf bagi seseorang yang bersalah. Nilai itu perlu diterapkan karena manusia di hadapan Allah adalah makhluk yang tidak berdaya apa-apa. Terkait dengan perilaku tidak menyinggung, toleransi itu bisa dilatih oleh orang yang berpuasa, terutama untuk menahan hawa nafsunya, yakni (11) tidak makan/minum di depan seseorang yang menunaikan puasa sehingga terbiasa santun sebagai sikap seseorang saling menghargai antarsesama, tidak sombong, dan tidak angkuh. Pada konteks sosial yang dinamis, terutama di lingkungan anak sekolah, nilai toleransi, yakni tidak membiarkan seseorang lalai melaksanakan ibadah perlu dikembangkan dengan membimbing hambanya menuju jalan yang benar.

Untuk itu, nilai, tidak memihak umat agama tertentu ketika memberikan bantuan sosial perlu dilakukan. Dengan begitu, seorang muslim memberikan contoh perilaku terpuji dan menerapkan kebajikan adalah dengan bersikap jujur dan amanah. Sebagai tindakan terpuji yang juga perlu dikembangkan, yakni tidak menutup jalan saat umat agama 
tertentu akan menunaikan ibadah dengan begitu timbul sopan santun harus dipraktikan dalam kehidupan sehari-hari, seperti terhadap orang tua, saudara, tetangga, teman, bahkan orang lain sekali pun.

Bila nilai tersebut diterapkan, seorang muslim perlu bertoleransi dengan tidak membiarkan orang lain mengganggu masyarakat beribadah. Sebagai muslim, isi pokok surah Al-Falaq adalah perintah terhadap umat Islam agar senantiasa berlindung kepada Allah dari segala bentuk kejahatan perlu diamalkan degan benar. Kejahatan sosial dapat muncul dalam pergaulan tanpa diduga sebelumnya. Itu perlu terus diwaspadai dengan melaksanakan nilai, yakni menciptakan kedamaian antaragama. Pada praktiknya, seseorang perlu berusaha mengajak orang lain kepada kebaikan dan mencegah kejahatan. Perbedaan pendapat antarwarga masyarakat itu tidak dapat dielakkan munculnya, tetapi dapat diantisipasi adanya, misalnya dengan nilai senang dan reseptif terhadap indahnya perbedaan beragama. Dengan begitu, berbeda itu wajar.

Seiring dengan itu, seseorang akan bersikap santun dan saling menghargai, persahabatanpun akan terjalin erat. Untuk itu, nilai menghargai individu dan perbedaan yang berbeda agama perlu dibiasakan. Seperti terungkap dalam buku kelas IV, yakni ketika bergaul dengan mereka kita harus bersikap santun dan menghargai mereka. Patut disyukuri bila nilai toleransi ini muncul beriring, yakni saling menghargai agama satu dengan yang lain sebagai aktualitasi dari sifat Rasulullah SAW. yang sangat bersikap rendah hati dan sopan terhadap semua orang. Kepekaan terhadap warga masyarakat, jiwa sosial tertentu diperlukan, yakni selaras dengan nilai menumbuhkan benih kepedulian dengan sikap menghormati biasanya dilakukan oleh orang yang lebih muda kepada orang yang lebih tua Dengan begitu, jiwa muslim akan terbentuk sebagai pribadi yang melaksanakan nilai toleransi beragama adalah cinta dan kasih sayang.

Cara itu menandakan bahwa seorang muslim mampu menjadi salah satu bentuk akhlak terpuji (mahmudah), rendah hati, dapat menimbulkan rasa persamaan, menghormati, dan menghargai orang lain, sikap toleran, sikap solidaritas sosial dan cinta kepada keadilan serta siap menerima kritik dan bersikap demokratis. Pada praktiknya, perilaku itu terwujud pula dengan nilai toleransi, menghargai kebaikan dalam diri orang lain, seperti tersirat dalam pernyataan kita harus berlatih dan membiasakan diri bersikap santun dan menghargai teman yang lain. Saat berada dalam lingkungan sosial, kesendirian perlu diwaspadai, terutama dalam menghadapi kesulitan. Itu merupakan aktualisasi nilai menghadapi situasi sulit bersama. Bila mengalami suatu masalah, seseorang tidak 
boleh berputus asa. Sebagai gambaran, sebagai pelajar muslim kita tidak boleh berputus asa meskipun dalam keadaan susah.

Nabi Musa A.S. dan Nabi Harun A.S. berjuang bersama mengembalikan umatnya ke jalan yang benar. Pada saat mengalami kesulitan, bisa saja, tumbuh jiwa menunjukkan kasih sayang terhadap sesama. Perilaku mulia itu tersirat dalam ungkapan berikut. Nabi Musa A.S. berhenti di sebuah tempat. Di sana ia melihat pengembala sedang mengambil air untuk kaming-kambing mereka. Di antaranya ada dua gadis yang sedang menunggu giliran mengambil air. Nabi Musa A.S. pun menolong kedua gadis tersebut. Dengan begitu, seseorang melaksanakan nilai, yakni mengasihi dan menyayangi makhluk Allah SWT. Sesuai dengan uraian itu, ada contoh yang relevan, yakni dari Abu Hurairah R.A. : Rasulullah SAW. Bersabda, "Barangsiapa beriman kepada Allah dan hari akhir (Kiamat), jangan menyakiti tetangganya. Dan barangsiapa yang beriman kepada Allah dan hari akhir (Kiamat), maka dia harus menghormati (menjamu) tamunya (H.R. Bukhari).

Pada saat kehidupan sosial semakin ramai, interaksi antaragama tidak dapat dihindarkan. Dalam kondisi itu, ada nilai tidak memaksakan agama pada orang lain. Namun, wajar bila terjadi perilaku begini, Pak Ustadz mengajak para murid untuk membaca Surah Al-Falaq dan AlMaun. dan Diskusikanlah arti dari isi kandungan surah Al-Fil secara berkelompok. Untuk itu, seorang muslim tidak perlu ragu. Sebaliknya, orang muslim justru perlu menggunakan iman dan amal sebagai basis toleransi, misalnya dengan menaati ajaran yang dibawa Rosul Allah SWT. Dengan melaksanakan segala hal yang diperintahkan dan menjauhi segala hal yang dilarang. Nilai toleransi itu sejalan dengan nilai menyadari kesetaraan antarumat beragama seperti tersirat dalam perilaku nabi.

Pada suatu hari Nabi Musa A.S. jalan-jalan melihat keadaan kota beliau bertemu dua orang yang berkelahi salah satu orang golongan Qibti (golongan kerajaan) yang satu dari golongan Bani Israil (golongan Nabi Musa). Ketika Nabi Musa A.S. hendak mendamaikan keduanya orang Qibti tidak mau berdamai dia sangat sombong karena merasa berasal dari golongan raja. Itu berarti bahwa seorang muslim bertoleransi dengan tidak menebarkan kebencian karena akan merugikan. Sebaliknya, sikap takabur atau sombong dapat menimbulkan sikap dengki, marah, dan egois. Apalagi nilai tidak mencontohkan kekerasan kepada sesama. Sudah tentu perlu dihilangkan, seperti contoh Ibu Nabi Harun A.S. pun merawat bayinya dengan penuh kasih sayang. Alangkah eloknya bila sejak dini, anak-anak telah diperkenalkan dan dibiasakan 
untuk menghargai tokoh agama non-Islam. Sikap itu, yakni sifat rendah hati telah dicontohkan oleh Rasullulah SAW.

Dalam pergaulan sehari-hari seperti beliau lebih dahulu mengucapkan salam, berjabat tangan, tidak membeda-bedakan orang lain dan sebagainya. Untuk itu, karena masyarakat perlu saling menghormati, tidak ada salahnya bila nilai menganjurkan mengucapkan selamat natal karena makin merekat komunikasi sosial tanpa kerugian religi masing-masing. Itu berat dilakukan, tetapi dapat dibiasakan. Dalam buku kelas IV, tercantum ungkapan, kita harus berlatih dan membiasakan diri bersikap santun dan menghargai teman lain. Untuk itu, mengutamakan jalan damai perlu dibudayakan, termasuk bersikap sabar dan tabah dalam menghadapi kesulitan dan kesusahan.

Sejalan dengan itu, penjelasan secara eksplanatif tentang nilai toleransi pada Buku Kelas V diuraikan berikut. Berkenaan dengan nilai tidak menertawakan cara beribadah umat beragama lain, terungkap contoh perbedaan pendapat yang tidak dapat diselesaikan dengan baik, dapat menimbulkan permasalah baru yang bisa menyebabkan permusuhan dan perkelahian. Seiring dengan itu, nilai toleransi tidak membicarakan kekurangan agama umat beragama lain juga tampak pada ungkapan tidak memcaci dan menjelekkan pendapat orang lain. Itu berarti bahwa seorang muslim tidak biasa mengatakan sesuatu yang bernada negatif, termasuk nilai tidak mencela aturan beribadah umat beragama lain yang dicontohkan dengan perilaku Mempertimbangkan tujuan dan dampak dari apa yang kita katakana.

Dengan begitu, perilaku nilai tidak membandingkan agama yang dianut dengan agama lain juga perlu dijaga. Dengan begitu, benar bahwa dalam buku kelas V dicantumkan ungkapan, permusuhan dan perkelahian tersebut bisa meneyebabkan perpecahan dan memutuskan tali silaturahmi; dan Allah SWT, juga telah mengisyaratkan, agar mengikuti apa yang paling baik jika ada perbedaan pendapat. Hal itu dapat dicegah dengan nilai toleransi tidak mencela aturan beribadah umat beragama lain sehingga orang muslim perlu dibiasakan untuk mempertimbangkan tujuan dan dampak dari apa yang kita katakana.

Perilaku nilai tidak menghalangi orang menunaikan agama sesuai dengan waktunya. Itu dapat terjadi seperti penjelasan dalam buku, yakni setiap umat yang durhaka di muka bumi ini, akan mendapat siksaan dari Allah. Allah akan mengganti mereka dengan umat yang baru. Begitulah perputaran hidup yang dijadikan oleh Allah. Untuk itu, nilai tidak melarang orang bersilaturahim saat hari besar agama tertentu perlu diwujudkan agar dapat saling mengigatkan dalam hal kebijakan termasuk perilaku mulia yang harus dilakukan setiap hari. Dalam hal sederhana, 
nilai tidak berisik bila sedang berlangsung ibadah di lingkungan tertentu. Umat Islam tidak boleh menganggap remeh. Seperti dicontohkan, sikap menghormati dapat diartikan sikap saling menghargai, sopan, patuh, atau suatu perbuatan yang menandakan ketundukan.

Agar mudah terealisasi, umat Islam memerlukan nilai tidak menyinggung agama seseorang saat berdebat tentang suatu masalah. Untuk itu, salah satu hikmah diturunkan Al-Quran secara bertahap adalah untuk mendidik masyarakat dan menyesuaikan hukum Islam secara bertahap. Sudah tentu, kesalahpahaman mungkin terjadi sehingga nilai tidak menutup pintu maaf bagi seseorang yang bersalah perlu diwujudkan. Contohnya, orang Islam ikhlas melakukan sesuatu, maka harus membuktikannya dengan melakukan perbuatan itu dengan sebaikbaiknya. Dalam perilaku keseharian, misalnya nilai tidak makan/minum di depan seseorang yang menunaikan puasa. Dalam buku dinyatakan bahwa puasa dapat melatih kesabaran dan pengendalian diri.

Seiring dengan itu, orang Islam perlu nilai tidak membiarkan seseorang lalai melaksanakan ibadah sehingga sudah diterakan selagi ada waktu dan umur, perbanyaklah berbuat kebajikan, seperti saling mengingatkan dalam kebaikan dengan cara memberi nasehat. Namun, nilai tidak memihak umat agama tertentu ketika memberikan bantuan sosial, penting. Pada buku dinyatakan, yakni segala sesuatu kalau tidak dibiasakan akan terasa berat untuk dilakukan, sebaliknya apabila sesuatu tersebut terbiasa dilakukan, akan terasa ringan. Selain itu, butir ini penting ditanamkan, yakni tidak menutup jalan saat umat agama tertentu akan menunaikan ibadah. Hal itu sejalan dengan QS. Al-Asr/103:1-3 “(1) Demi masa, (2) sungguh, manusia berada dalam kerugian. (3) kecuali orang-orang yang beriman dan mengerjakan kebajikan serta saling menasihati untuk kebenaran dan saling menasihati untuk kesabaran. Memang, nilai toleransi tidak membiarkan orang lain mengganggu masyarakat beribadah, perlu diwujudkan.

Senada dengan itu, ada nilai menciptakan kedamaian antaragama. Itu terungkap dalam contoh Allah akan memberikan pahala yang tidak ada putus-putusnya bagi orang-orang beriman dan mengerjakan kebajikan. Saling mengingatkan dalam hal kebajikan termasuk salah satu contoh dari kebajikan. Selain itu, nilai ini juga perlu ditanamkan, yakni senang dan reseptif terhadap indahnya perbedaan beragama, berterima pada perbedaan. Itu terlihat pada ungkapan Islam memberikan tuntuan bagaimana harus bersikap ketika menghadapi perbedaan pendapat. Secara praktis, hal itu merupakan nilai, yakni menghargai individu dan perbedaan yang berbeda agama yang dicontohkan oleh ulama. Dalam buku dijelaskan, yakni para ulama tidak saling mecaci, dan mencela, 
tetapi mereka saling melengkapi. Dengan begitu, timbul pula nilai, yakni saling menghargai agama satu dengan yang lain yang dicontohkan dalam buku, yakni perbedaan bisa menjadi alat pemersatu,jika perbedaaan pendapat tersebut di sikapi dengan bijak dan benar.

Dengan begitu, nilai, yakni menumbuhkan benih kepedulian perlu dilaksanakan. Pada praktiknya, nilai itu tambak dalam buku, yakni saling mengingatkan dalam kebaikan bisa dilakukan dengan cara saling menasehati,tentunya menasehati dalam hal kebaikan. Bila itu dilakukan, nilai toleransi mudah terealisasi, yakni toleransi beragama adalah cinta dan kasih sayang. Secara tegas, nilai itu dicontohkan, yakni Suatu ketika, Nabi Sulaiman A.S. pergi dengan rombongan besar yang terdiri atas manusia, binatang, dan jin. dan di tengah perjalanan, tepatnya ketika beliau dan rombongannya melewai sebuah lembah, ketika itu beliau mendengar seekor semut berbisik kepada kawannya "masuklah kalian ke dalam sarang, supaya kalian selamat dan tidak terinjak oleh Sulaiman dan rombongannya." Nabi Sulaiman A.S. tersenyum mendengar suara semut yang ketakutan itu.

Selain itu, ada juga nilai, yakni menghargai kebaikan dalam diri orang lain. Itu dicontohkan, yakni Rasulullah SAW adalah sosok teladan dalam hal menghargai pendapat. Rasulullah SAW tidak mencela salah satu di antara orang yang berbeda pendapat. Apalagi, seseorang kadang dalam keadaan sulit, nilai menghadapi situasi sulit bersama. Kebersamaan diperlukan. Itu diwujudkan dengan saling menolong merupakan kewajiban bagi setiap umat manusia. Dengan begitu, nilai mudah terealisasi, yakni menunjukkan kasih sayang terhadap sesama, seperti dicontohkan dalam buku, yakni Saling mengingatkan dalam kebajikan di lingkungan masyaraka. Hal itu wajar karena terdapat nilai, yakni mengasihi dan menyayangi makhluk Allah SWT yang dicontohkan dalam buku, yakni Selain hormat kepada orang tua, kita juga harus menghormati guru dan sesama anggota keluarga.

Dengan kasih sayang itu, nilai tidak memaksakan agama pada orang lain, seperti dicontohkan dalam buku, yakni Pak Ustadz mengajak para murid untuk membaca Surah Al-Falaq dan Al-Maun; dan Diskusikanlah arti dari isi kandungan surah Al-Fil secara berkelompok. Untuk itu, perlu nilai yakni menggunakan iman dan amal sebagai basis toleransi, seperti contoh dalam buku, yakni meneladani ketaatan, sikap dan perilaku terpuji Rasul-Rasul Allah SWT. Untuk itu, perlu nilai, yakni menyadari kesetaraan antarumat beragama yang dicontohkan dalam buku, yakni Perbedaan pendapat yang tidak dapat diselesaikan dengan baik, dapat menimbulkan permasalahan baru yang dapat menyebabkan 
permusuhan dan perkelahian. Seiring dengan itu, nilai toleransi, yakni tidak menebarkan kebencian, perlu ditegakkan.

Untuk itu, nilai tidak mencontohkan kekerasan kepada sesame, perlu. Sebaliknya, contoh, yakni Selalu menunjukkan akhlak yang terpuji baik kepada teman ataupun lawan, juga penting. Alangkah eloknya bila nilai-nilai itu terwujud, yakni menghargai tokoh agama non-Islam. Itu dilakukan dengan bersikap sederhana adalah sikap bersahaja ,tidak berlebih-lebihan. Dengan demikian, nilai toleransi, yakni menganjurkan mengucapkan selamat natal. Cara itu dicontohkan dalam buku, yakni perbedaan pendapat tersebut harus kita hargai, karena setiap orang pasti memiliki alasan tertentu mengapa dia berpendapat seperti itu. Dengan demikian, nilai toleransi ini juga amat penting, yakni mengutamakan jalan damai, seperti dicontohkan dalam buku, yakni perbedaan pendapat kalau tidak disikapi dengan biaksana, maka akan melahirkan perpecahan dan permusuhan. Oleh karena itu, Islam memberikan tuntunan bagaimana harus bersikap ketika menghadapi perbedaan pendapat.

Pada hakikatnya, setiap manusia terlahir dalam keadaan suci. Oleh Allah SWT., manusia dibekali dengan sistem pada jiwa raganya, baik biologis maupun religius. Secara biologis, bayi berkembang menjadi anak, remaja, dan dewasa. Akan tetapi, ada sistem lain yang harus diintegrasikan di dalam diri seseorang. Untuk itu, intergrasinya pun tidak dapat dilaksanakan mendadak. Itu disebabkan oleh perlunya waktu berproses. Pada saat berproses, terjadilah pertemuan seseorang dengan sejawatnya, bahkan berinteraksi dengan orang yang lebih muda atau berjumpa dengan orang tua. Saat seseorang berproses menjadi jiwa yang makin matang, sistem yang berpengaruh dalam jiwanya juga akan bertemu dengan sistem di masyarakat. Jika keadaan itu muncul pada diri seseorang dan masyarakat, individu tidak boleh memaksakan diri. Alasannya, setiap pergerakan dalam kehidupan sehari-hari selalu bersinggungan dengan individu lain. Selain itu, setiap perkembangan jiwa dalam kebersamaan di masyarakat juga akan beririsan dengan keyakinan dalam keberagaman yang dinamis. Untuk itu, menerapkan toleransi harus dididikkan,

Realitas pergerakan jiwa raga manusia pada pembahasan ini sengaja dibatasi pada tiga lingkungan, yakni rumah, sekolah, dan masyarakat. Dengan pembatasan itu, hal toleransi dibahas pada saat sang anak memerlukan didikan di rumah, saat siswa mengharapkan pelajaran di sekolah, serta saat seseorang mendapatkan relasi sosial di masyarakat. Seperti terungkap bahwa 
"Mereka justru terpapar oleh intoleransi terhadap teman sejawatnya sehari-hari, seolah tidak menghargai orang lain, tidak memahami agama, tidak menghargai nilai-nilai moral dan budaya masyarakat ${ }^{18}$. Pada konteks fluktuatif situasi sosial itu, saat berlangsung pendidikan informal, orang tua dan guru semestinya bekerjasama yang apik untuk mendidik putra-putrinya. Akan tetapi, seiring dengan maraknya budaya persekolahan, pembentukan watak anak bangsa kerap diserahkan kepada pihak sekolah (baca: guru) melalui pelajaran pendidikan agama Islam. Pada peran itu, guru menanggung beban tanggung jawab yang relatif berat karena ada tuntutan untuk menyiapkan pendidikan yang profesional, termasuk menciptakan suasana pembelajaran yang berkarakter misalnya bertoleransi, bereligius, bermoral, dan beretika di sekolah dan berbudaya di masyarakat ${ }^{19}$.

Dengan begitu, pembatasan pada tiga lingkup itu dapat memudahkan pemberian contoh, sekaligus memperjelas penekanan penerapan toleransi dalam kehidupan sehari-hari.

Toleransi, pada prinsipnya, merupakan perilaku kejiwaan seseorang. Namun, mereka dapat diberi pemahaman terhadap apa yang seharusnya tidak dilakukan, serta apa saja yang sebaiknya dilakukan dengan pertimbangan yang bijak. Dari lingkungan rumah, seorang anak memiliki hak hidup yang harus dijaga oleh orang tua, terutama orang tua kandung. Atau, mungkin juga dilakukan oleh orang dewasa yang hidup di lingkungan keluarga. Hal-hal yang harus dilakukan oleh orang dewasa terhadap sang anak, misalnya, menyediakan kebutuhan sehari-hari secara fisik, baik tempat yang wajar, baik untuk istirahat maupun untuk bermain, apalagi untuk belajar. Itu seharusnya disiapkan oleh orang dewasa, terlebih orang tua kandung. Dari tempat yang dihuninya, anak akan sadar ruang bahwa ada tempat yang harus dirawat dan dijaga selazimnya. Untuk

18 Triwiyanto Teguh, Gelombang Liberalisme Pendidikan: Mengawal Tata Kelola Pendidikan untuk Rakyat. (Jakarta: PT Kompas Media Nusantara,2019),h.14

ibid, Membangun dan Mengembangkan Human Capital Unggul melalui Pendidikan, Kinerja, dan Produktivitas Kerja di Era 4.0, (Bandung: PT Refika Aditama, 2020),h.6

${ }^{19} \mathrm{Ibid}$, Pengembangan Kurikulum Pendidikan Agama Islam di Sekolah, Madrasah, dan Perguruan Tinggi, (Jakarta: PT Raja Grafindo Persada, 2005),h.55

Ibid, Pendidikan Karakter sebagai Fondasi Keterampilan Abad 21 (5CS Super Skills), (UNS : Pidato Pengukuhan Guru Besar Bidang Ilmu Pendidikan 5 November, 2019), h.32 
itu, orang tua harus memberikan contoh sejak dini secara nyata, bukan hanya memerintah anak untuk menjaga huniannya.

Bila tersadarkan pada lingkungan tempat tinggalnya, anak akan mengerti bahwa tidak dibenarkan bila memasuki lingkungan orang lain, mulai dari kamar anggota keluarga, perkarangan tetangga, apalagi masuk ke dalam rumah orang lain. Ini berarti bahwa akan tertanam kebiasaan tidak dibenarkan memasuki kawasan orang lain. Dari rumah, anak harus dibantu, diberi tahu, bahkan diberi contoh. Ini merupakan tugas orang dewasa, terutama orang tua kandung. Bila itu berlangsung seiring dengan pertumbuhan dan perkembangan anak, kesadaran untuk bertenggang rasa menempatkan diri pada lingkungan baru pada masa akan datang akan terbentuk dalam jiwanya. Itu merupakan gambaran bahwa penanaman berkehidupan sebagai pribadi sang anak sejak di lingkungan keluarga yang masih menjadi tanggung jawab keluarga. Sudah tentu, tugas itu relatif berat karena mengharuskan orang tua memedulikan anak dari segala aspeknya. Sudah banyak bukti bahwa kehidupan sosial anak, baik di sekolah maupun di masyarakat "berantakan", bukan hanya membahayakan dirinya, tetapi nyaris merusak orang/masyarakat tempat pergaulan sosialnya.

Untuk tidak terjadi peluang demikian, kembali ke fokus penanaman pembiasaan berkehidupan sosial di rumah, orang tua tidak boleh membiarkan anak keluar rumah, termasuk ke sekolah, seorang diri secara bebas. Jangankan di perjalanan menuju sekolah, saat anak di rumah, kadang tertembus pengaruh masuknya multinilai melalui media sosial. Untuk itu, ketika anak menuju lingkungan sekolah, orang tua harus memperhatikan perjalanan. Masalahnya, di jalan raya juga akan terjadi pertemuan, bahkan persinggungan dengan orang lain, yang kurang lebih, mereka memiliki keperluan yang sama, yakni perjalanan menuju ruang/tempat aktivitas. Bagi sang anak, pengenalan toleransi yang telah dipahami di lingkungan rumah bersama anggota keluarga akan diterapkan di lingkungan sosial menuju sekolah. Sesampainya di lingkungan persekolahan, anak tidak dapat dilepas begitu saja. Makanya, pendidikan usia dini dibuka, bukan untuk menguasai keilmuan, tetapi lebih menempa anak dalam lingkungan hidup yang meluas.

Keberadaan anak usia sekolah dasar di lingkungan sekolah tidak boleh diserahkan begitu saja kepada para gurunya. Pada masa nonpandemi, jumlah guru dan jumlah siswa terus berubah dan berkembang, bahkan bertambah banyak. Tanggung jawab guru tentu kompleks sehingga tidak dapat mengawasi anak satu per satu. Dari keluarga anak yang baik, belum tentu anak dalam kondisi psikis yang baik juga. Apalagi, dari kelurga yang relatif kurang terkendali, anak 
dikhawatirkan memiliki pribadi labil. Pada semua kondisi itu, bila setiap orang tua menyerahkan anaknya kepada para guru di sekolah, besar kemungkinan anak kurang terjaga keamanannya, bahkan keselamatan anak tidak dapat dijamin. Permasalahannya, ancaman pada anak, yaitu pengaruh pergaulan sosial yang tidak terkontrol dengan baik.

Pada kekhawatiran itu, setelah orang tua memperhatikan kehidupan anak di rumah, orang tua perlu melakukan koordinasi yang transparan dengan guru, baik secara personal maupun kolektif. Secara personal, orang tua dapat bekerja sama dengan guru, misalnya berkomunikasi tentang kebiasaan anak, apakah anaknya pemalu, pemarah, atau anak yang perokok. Melalui pendekatan personal, guru dapat menyambut anak dengan pemahaman yang tepat. Dengan begitu, guru akan mendampingi pertumbuhan dan perkembangan anak di sekolah agar tidak berpengaruh kepada teman sejawatnya. Agar anak tidak menjadi sasaran ejekan/olokan teman sejawatnya. Bila kondisi pribadi anak tidak diberitahukan oleh orang tua secara terbuka kepada guru, mungkin guru tidak mengontrolnya secara khusus. Pada batas kewajaran, di setiap persekolahan telah disiapkan guru bimbingan dan penyuluhan agar anak yang dikenali secara khusus dapat dipedulikan sejak awal masuk sekolah. Bila tidak, boleh jadi, persinggungan antarsesama teman akan berlangsung sehingga toleransi yang dibentuk di lingkungan rumah dengan baik, justru terbentur dengan lingkungan sosial yang fluktuatif.

Selain dengan koordinasi personal, orang tua siswa dapat bekerja sama dengan sesama orang tua. Itu melalui komite sekolah. Orang tua harus saling mengenal orang tua teman putra-putrinya. Secara psikis, pemahaman bahwa orang tua bekerjasama dengan baik, tentu mengundang perhatian siswa. Dengan begitu, ada imbas yang dapat tertanam pada jiwa siswa. Untuk itu, baik melalui koordinasi dengan pihak sekolah ataupun koordinasi antarorang tua, kegiatan yang melibatkan para siswa perlu digelar. Dalam hal ini, bukan mahal dan besarnya biaya yang diukur, tetapi bobot aktivitas yang dapat ditiru oleh siswa. Setidaknya, antarsiswa saling mengenal sehinga sifat bersahabat, rukun, peduli, dapat terbangun secara kolektif-masif, bahkan berdampak pada pergaulan social. Pada situasi sosial itu, kekhawatiran anak, termasuk keraguan orang tua atas keselamatan anak menempuh pendidikan persekolahan dapat diminimalkan. Itu menandakan orang tua dan guru bekerja sama yang cermat untuk menata lingkungan pergaulan social.

Saat di sekolah, sulit dielakkan munculnya persinggungan antarsesama siswa. Kesulitan itu terpicu oleh kondisi demografis sekolah, yakni beragamnya latar siswa, baik dari lingkungan sosial, ekonomi, 
politik, bahkan religi yang berkembang di lingkungan keluarga. Bila persingungan itu tidak terjaga, besar kemungkinan akan terjadi intoleransi yang justru dilakukan oleh sesama siswa, baik mulai perilaku sederhana maupun perbuatan yang luar biasa. Sebagai gambaran, sebagian siswa yang berasal dari latar belakang sosial ekonomi terbatas, mereka kurang percaya diri di sekolah. Pada kondisi itu, sebagian siswa yang berasal dari latar sosial ekonomi menengah, mereka kadang kurang mampu mengontrol diri sehingga timbul sikap angkuh. Padahal, itu tidak perlu terjadi dan dapat diantisipasi. Sebagai gambaran lain, siswa di sekolah berasal dari agama dan budaya yang berbeda. Pada kondisi itu, sebagian siswa yang berasal dari keluarga "ekstrim" kadang agak tertutup sehingga enggan berinteraksi dengan sejawatnya. Perilaku eksklusifisme berbahaya karena dapat memecah nilai persahabatan mereka. Pada gilirannya, ketika menamatkan pendidikan, benih kesan perpecahan tertanam. Tidak tertutup kemungkinan berkembang menjadi permusuhan. Apa yang terjadi, tawuran antarkelompok, bahkan tawuran antarsekolah berlangsung begitu menyeramkan, hingga menimbulkan korban jiwa. Di sinilah, toleransi harus dibumikan ke dalam jiwa siswa dengan cara yang kreatif.

Bertolak dari konseptual tersebut, nilai-nilai toleransi ditelusuri dari beragam sumber. Sejauh temuan peneliti berdasarkan telaah referensi tersebut dapat dikatakan terdapat 35 nilai-nilai toleransi yang perlu ditanamkan ke dalam jiwa para siswa, baik di rumah maupun di sekolah. Akan tetapi, mengingat begitu beragamnya nilai toleransi, cara-cara yang ditempuh tentu beragam. Sebagai gambaran, toleransi peduli pada orang lain, terutama terhadap mereka yang memerlukan bantuan, para siswa bisa dilibatkan mengumpulkan bantuan untuk disumbangkan kepada pihak yang memerlukan. Mereka bekerjasama antarteman melaksanakannya. Toleransi untuk peringatan hari besar agama, sebagian siswa sebatas mendukung pelaksanaan peringatan hari besar agama tertentu di suatu sekolah tanpa terlibat dalam peribatannya. Praktik toleransi beragama itu tertanam di sekolah tanpa ada pihak yang mengintervensi. Selain itu, toleransi untuk menghargai pendapat orang lain dilakukan secara demokratis. Biasanya, di bawah komando guru mata pelajaran PPKn, para siswa bermusyawarah untuk menemukan solusi atas masalah yang dihadapinya, mulai masalah kecil di sekolah sebagai bahan simulasinya sampai dengan masalah besar di masyarakat. Pendek kata, nilai-nilai tersebut kompleks sehingga perlu kesabaran untuk memilih dan memilah setiap nilai untuk ditanamkan pada situasi sosial yang tepat.

Strategi itu dapat diterima asal ada kerjasama orang tua dengan pihak sekolah agar pelatihan bertoleransi dapat terlaksana lancar. Akan 
tetapi, pihak sekolah perlu menemukan alternatif jalan untuk menemukan kesempatan terbaik dalam menanamkan roleransi kepada para siswa usia pendidikan dasar. Untuk itu, guru kadang memberi teladan bertoleransi dengan sesama teman sejawat sehingga dapat dilihat dan dipahami oleh para siswa bahwa ada toleransi yang dicontohkan oleh guru secara langsung. Itu terlihat dari kerjasama guru dalam peringatan hari besar di sekolah, lomba kreatif antarsiswa yang didukung para wali kelas, sampai dengan kebersamaan guru dalam KKG. Sekilas, aktivitas guru tidak relevan dengan pentingnya penanaman toleransi pada jiwa siswa. Sebaliknya, kebersamaan guru dapat menjadi cermin bagi siswa untuk membiasakan kebersamaan. Jadi, keteladanan dicontohkan, bahkan ditunjukkan secara nyata

Meskipun begitu, penanaman toleransi kepada siswa dapat dilakukan melalui pembelajaran. Pada kondisi kelas hiterogen, guru tidak boleh berpihak pada siswa tertentu. Siswa dari beragam latar belakang harus dipedulikan berimbang. Artinya, dalam pembentukan kelompok, penantaan kelompok belajar, penyusunan jadwal piket kebersihan, penyiapan tim lomba antarkelas, serta pemberian bantuan kepada siswa yang memerlukannya. Guru harus memberikan pembelajaran toleransi secara praktis, bukan sekadar dianjurkan untuk bekerjasama. Pada usia $\mathrm{SD}$, siswa memerlukan pendampingan yang penuh kesabaran. Bila perlu, guru berpartisipasi aktif di dalam kelompok. Itu dimaksudkan agar guru dapat meluruskan dan membetulkan kesalahan. Bila tidak terjaga, kemungkinan pembelajaran menghasilkan prestasi unggul, tetapi lebih menekankan keilmuan, bukan praktik sosial yang seharusnya diutamakan. Di sinilah, guru harus peka atas keberagaman siswa agar penentuan kebijakan dapat mencerminkan keadilan: kebersamaan dalam keberagaman yang penuh toleransi.

Dari pemikiran itu, partisipasi aktif guru amat penting, bahkan strategis karena substansi toleransi kerap berada dan berasal dari pendidikan mental yang paling mendasar, yakni pendidikan kalbu (hati) menggunakan ilmu agama. Bila baik hati seseorang, akan baik pula perilaku selanjutnya. Itu menandakan peran yang dilakukan guru PAI lebih berat dibandingkan dengan bidang lain. Untuk itu, selaku peneliti aspek toleransi di dunia pendidikan dasar, peneliti memfokuskan perhatian pada aktualisasi toleransi dalam buku pelajaran pendidikan agama Islam bagi siswa kelas IV dan kelas V. Alasannya, para siswa kelas IV sudah mampu berpikir logis sehingga perlu disiapkan paparan toleransi yang faktual dan aktual dalam buku pelajaran pendidikan agama. Melalui penelitian ini, peneliti dapat memetakan bahwa sebaran nilai 
toleransi ternyata telah tersebar dalam buku pendidikan agama Islam kelas IV dan kelas V.

\section{PENUTUP}

Penutup ini berisi kesimpulan dan saran sesuai dengan permasalahan. Setelah dianalisis, nilai-nilai toleransi dalam buku "Senang Belajar Agama Islam dan Budi Pekerti” bagi Siswa Kelas IV dan V SD di Kab. Karanganyar terdiri atas 31 nilai toleransi yang tersebar. Berdasarkan simpulan itu, saran yang perlu diberikan kepada (1) penulis buku pendidikan agama Islam untuk siswa kelas IV dan V SD, (2) guru pendidikan agama Islam kelas IV dan V SD, (3) siswa kelas IV dan V SD, dan (4) kepala SD, sebagai berikut. Penulis buku pendidikan agama Islam SD kelas IV dan $\mathrm{V}$ perlu menempatkan sebaran nilai toleransi pada sebaran yang berimbang pada setiap bab agar nilai toleransi dapat dikenal dan dipelajari oleh siswa bagian demi bagian. Untuk itu, nilai-nilai toleransi dalam buku pendidikan agama Islam perlu dilengkapi teks dan gambar yang kontekstual dengan kehidupan anak usia sekolah dasar. Guru pendidikan agama Islam siswa kelas IV dan V SD perlu membaca dengan cermat, bahkan menelusuri keberadaan nilai toleransi agar dapat diajarkan secara berkelanjutan, bagian demi bagian, sesuai dengan situasi pembelajaran di lingkungan masing-masing. Para siswa kelas IV dan V SD perlu membaca dan menerapkan nilai toleransi yang tersebar dalam buku dengan berkonsultasi pada orang tua dan guru yang membinanya seharihari. Kepala SD dapat menjadikan sebaran nilai-nilai toleransi sebagai panduan untuk memilih, menentukan, dan merancang kegiataan sosial kemasyarakatan di sekolah untuk melatih kepekaan siswa menjadi generasi yang toleran.

\section{DAFTAR PUSTAKA}

A., Doni Koesoema. (2012). Pendidikan Karakter Utuh dan Menyeluruh. Yogyakarta: Kanisius.

Agung S., Leo. 2019. Pendidikan Karakter sebagai Fondasi Keterampilan Abad 21 (5CS Super Skills). Pidato Pengukuhan Guru Besar Bidang Ilmu Pendidikan, UNS, 5 November 2019.

Ahmad. Musta'in. (2017). Peran Kemenag Dalam Pencegahan Radikalisme, Intoleransi \& Terorisme. http://karanganyar.kemenag.go.id/berita/read/-peran-kemenagdalam-pencegahan-radikalisme-intoleransi-terorisme. Di-unduh 27 September 2020, pukul 23.20 WIB.

Al-Qaradhawi, Yusuf. (2007). Muntakhab Ahadits: Dalil-dalil Pilihan Enam Siaf Utama. Cet. Ke-II. Yogyakarta: Ash-Shaff. 
Al-Qur'an al-Karim.

Aly, Abdullah. (2011). Pendidikan Islam Multikultural di Pesantren: Telaah terhadap Kurikulum Pondok Pesantren Modern Islam Assalam Surakarta. Yogyakarta: Pustaka Pelajar.

Arif, Syaiful. (2018). Islam, Pancasila, dan Deradikalisasi. Jakarta: Gramedia.

Atmanto, Nugroho Eko. SIKAP TOLERANSI SISWA MADRASAH(Pandangan Siswa Madrasah Aliyah Negeri 1 Kendal terhadap Toleransi Antar Umat Beragama).https://simlitbangdiklat.kemenag.go.id/simlitbang/spda ta/upload/dokumenpenelitian/1557990953Exsum_Penelitian_Tole ransi_SMA.pdf. diunduh 28 Januari 2020, pukul 19.30 WIB.

Bakry, Noor Ms. (2010). Pendidikan Pancasila. Yogyakarta: Pustaka Pelajar.

Bungin, M. Burhan. (2009). Penelitian Kualitatif: Komunikasi, Ekonomi, Kebijakan Publik, dan Ilmu Sosial Lainnya. Jakarta: Kencana Prenada Media Group.

Darno. (2020). Waspadai Bullying di Sekolah, Begini Langkah Pemkab Sukoharjo https://m.solopos.com/waspadai-bullying-di-sekolahbegini-langkah-pem-kab-sukoharjo1048555?utm_source=bacajuga_desktop. Diunduh 27 September 2020, pukul 22.20 WIB.

Dja'far, Alamsyah M.2018. Intoleransi! Memahami Kebencian dan Kekerasan atas Nama Agama. Jakarta: PT Elex Media Komputindo.

Dosensosiologi.com. (2019). Pengertian Toleransi Beragama, Manfaat, dan Contohnya di Masyarakat https://dosensosiologi.com/toleransi-beragama. Diunduh 1 September 2020, pukul 19.30 WIB.

Drew, Clifford J.; Hardman, Michael L.; dan Hosp, Jonh L. (2017). Penelitian Pendidikan: Merancang dan Melaksanakan Penelitian pada Bidang Pendidikan. Jakarta: PT Indeks.

Elfindri.; Hendrajaya, Lilik.; Wello, Muhammad Bahkri.; Hendmaidi.; Eriyani, Elfa.; dan Indra, Ristapawa. (2012). Pendidikan Karakter: Kerangka, Metode, dan Aplikasi untuk Pendidik dan Profesional. Jakarta: Baduose Media.

Furqon M. 2019. Analisis Nilai-Nilai Toleransi dalam Buku Teks Mata Pelajaran Pendidikan Agama islam dan Budi Pekerti Tingkat SMA Terbitan Kemendikbud tahun 2017. Tesis. (http://etheses.uin- 
malang.ac.id/13237/1/16771006.pdf) Diunduh 25 Juni 2021 Pkl 20.00 WIB.

Geovanie, Jeffrie. (2013). Civil Religion: Dimensi Sosial Politik Islam. Jakarta: Gramedia Pustaka Utama.

Geovavanie, Jeffrie. (2013). Civil Religion: Dimensi Sosial Politik Islam. Jakarta: Gramedia Pustaka Tama.

Ghozaly, Feisal and Achmad Buchori Ismail. (2017a). Pendidikan Agama Islam dan Budi Pekerti, Buku Guru Kelas 4. Vol. 8. Jakarta: Pusat Kurikulum dan Perbukuan, Balitbang, Kemendikbud.

Ghozaly, Feisal and Achmad Buchori Ismail. (2017b). Pendidikan Agama Islam dan Budi Pekerti, Buku Guru Kelas 5 SD. Vol. 8. edited by Samsuri. JAKARTA: Pusat Kurikulum dan Perbukuan, Balitbang, Kemendikbud.

Ghozaly, Feisal. dan Ismail, Buchori Achmad. (2014). Buku Guru Pendidikan Agama Islam dan Budi Pekerti SD/MI Kelas IV. Jakarta: Kementerian Pendidikan dan Kebudayaan.

Ghufron, Fathorrahman. (2016). Ekspresi Keberagaman di Era Milenium: Kemanusiaan, Keragaman, dan Kewarganegaraan. Yogyakarta: IRCiSoD.

Gulen, Muhammad Fetullah. (2013). Membangun Peradaban Kita: Islam adalah Masa Depan Dunia yang Memuliakan dan Menjunjung Tinggi Derajad Manusia. Jakarta: Penerbit Republika.

Hasanah, Silva K. 2019. Nilai Toleransi dalam Kurikulum Pendidikan Agama Islam di Sekolah Berdasarkan Permendikbud nomor 21 Tahun 2016. Malang: Jurusan Pendidikan Agama Islamfakultas Ilmu Tarbiyah Dan Keguruanuniversitas Islam Negeri Maulana Malik Ibrahim. http://etheses.uinmalang.ac.id/16291/1/15110117.pdf. diunduh 25 Januari 2021, pukul 20.00 WIB.

Hikam, Muhamad A.S. (2000). Islam, Demokratisasi, dan Pemberdayaan Civil Society. Jakarta: Penerbit Erlangga.

Indrayani (Ed.). (2012). Pendidikan Karakter: Kerangka, Metode, dan Aplikasi untuk Pendidik dan Profesional. Jakarta: Baduode Media Jakarta.

Irwantoro, Nur. dan Suryana, Yusuf. (2016). Kompetensi Pedagogik: untuk Peningkatan dan Penilaian Kinerja Guru dalam Rangka Implementasi Kurikulum Nasional. Surabaya: Genta Group.

Ismawati, Esti. (2012). Telaah Kurikulum dan Pengembangan Bahan Ajar. Yogyakarta: Penerbit Ombak. 
Khalsa, Siri Nam S. (2008). Pengajaran dan Disiplin Harga Diri. Jakarta: PT Indeks.

Koesoema, Doni. (2012). Pendidikan Karakter Utuh dan Menyeluruh. Yogyakarta: Penerbit Kanisius.

Mahya, Itaf Bareeq. (2014). Mendidik Anak ala Rasulullah sejak dalam Kandungan sampai Usia 18 Tahun. Klaten: Abata Press.

Malik, Hermen. (2016). Membangun Generasi Berperadaban. Yogyakarta: INDes Publishing.

Mansur, Sufa'at. (2012). Toleransi dalam Agama Islam. Yogyakarta: Harapan Kita.

Mawarti, Sri. (2017). Nilai-Nilai Pendidikan Toleransi Dalam Pembelajaran Agama Islam. Pekanbaru: puslit.lppm@uinsuska.ac.id.

Misrawi, Zuhairi. (2007). Al'Quran Kitab Toleransi: Inklusivisme, Pluralisme, dan Multikulturalisme. Jakarta: Penerbit Fitrah.

Misrawi, Zuhairi. 2007. Alquran Kitab Toleransi: Insklusivisme, Pruralisme, dan Multikulturalisme. Jakarta: P3M.

Muhaimin. (2005). Pengembangan Kurikulum Pendidikan Agama Islam di Sekolah, Madrasah, dan Perguruan Tinggi. Jakarta: PT Raja Grafindo Persada.

Muhammad, Sayid. (2016). Sejarah Perjuangan Rasulullah: Menelusuri Kisah Hidup, Perjuangan, an Dakwah Sang Rasul dalam Menyebarkan Islam. Solo: Aryhaeko Sinergi Persada.

Muqoyyidin, Andik Wahyun. (2012). Dialektika Islam dan Budaya Lokal dalam Bidang Sosial sebagai Salah Satu Wajah Islam Jawa. Artikel dalam El Harakah, Jurnal Budaya Ilslam, Vol. 14, No. 1 Januari-Juni 2012, hlm. 18-33.

Nasution, S. (2008). Asas-asas Kurikulum. Jakarta: Bumi Aksara.

Nizar, Samsul. (2013). Sejarah Sosial dan Dinamika Intelektual: Pendidikan Islam di Nusantara. Jakarta: Prenada Media Group.

Purwanto. (2020). Panduan Penulisan Tesis (S-2) dan Disertasi (S-3) Pascasarjana IAIN Surakarta. Surakarta: Pascasarjana.

Prastowo, Andi, Panduan Kreatif Membuat Bahan Ajar Inovatif, Yogyakarta: Diva Press, 2012.

Rahmanto A. 2019. Nilai Toleransi Beragama dalam Buku Akidah Akhlak dan Implementasinya pada Pembelajaran di SMA Muhammadiyah Satu Bantul Yogyakarta. Tesis. (https://digilib.uin-suka.ac.id/id/eprint/39029/). Diunduh 25 Juni $2021 \mathrm{Pkl} 20.00$ WIB. 
Ratna, Nyoman Kutha. (2010). Metodologi Penelitian: Kajian Budaya dan Ilmu Sosial Humaniora pada Umumnya. Yogyakarta: Pustaka Pelajar.

Rusydiyah, Evi Fatimatur. (2019). Aliran dan Paradigma Pemikiran Pendidikan Agama Islam Kontemporer. Surabaya: UIN Sunan Ampel Press.

Sedarmayanti.; Komariah, Aan.; Kurniady, Dedy Achmad; Zafar, Tetty Sufianty. 2020. Membangun dan Mengembangkan Human Capital Unggul melalui Pendidikan, Kinerja, dan Produktivitas Kerja di Era 4.0. Bandung: PT Refika Aditama.

Shihab, Muhammad Quraish. (1996). Wawasan AlQur'an.Bandung:Mizan.

Sholeh, M. Asrorun Ni'am. dan Humaidi, Lutfi. (2016). Panduan Sekolah \& Madrasah Ramah Anak. Jakarta: Penerbit Erlangga.

Soryani, Sri. 2015. Penanaman Sikap Toleransi Di Kelas V SD Negerisiyono Iiikecamatan Playen Kabupaten Gunungkidul. Yogyakarta: Program Studi Pendidikan Guru Sekolah Dasarjurusan Pendidikan Prasekolah dan Sekolah Dasar. Fakultas Ilmu Pendidikanuniversitas Negeri Yogyakarta. http://eprints.uny.ac.id/23981/1/Skripsi\%20Sri\%20Soryani\%2011 108241059.pdf. diunduh 25 Januari 2021, pukul 20.00 WIB.

Subadio. (2012). Peningkatan Mutu Pendidikan Dasar dan Menengah di Provinsi Banten Melalui Manajemen Berbasis Sekolah. Artikel dalam Jurnal Penelitian dan Evaluasi Pendidikan, Tahun 16, Nomor 2, 2012, hlm.553-573.

Sudrajat, Ajat; Samsudin, Amir; Ratnasari, Amir; Marzuki, Mami Hajaroh; Suparlan; Fathudidin, Syukri; Fitria Vita. 2013. Din AlIslam. Yogyakarta: UNY Press.

Sukmadinata, Nana Syaodih. (2010). Pengembangan Kurikulum Teori dan Praktik. Bandung: PT Remaja Rosdakarya.

Sularto, St. dan Paramita, Amalia (Ed.). (2017). Nilai Ke-Indonesia-an: Tiada Bangsa yang Besar Tanpa Budaya yang Kokoh. Jakarta: PT Kompas Media Nusantara.

Supardi, Moh. Masrum; Musafak; Suradi; dan Chaeroni. (2016). Senang Belajar Agama Islam dan Budi Pekerti untuk SD Kelas IV. Jakarta: Penerbit Erlangga.

Supardi, Moh. Masrum; Musafak; Suradi; dan Chaeroni. (2016). Senang Belajar Agama Islam dan Budi Pekerti untuk SD Kelas V. Jakarta: Penerbit Erlangga. 
Suprayoga, Imam. (2016). Toleransi dalam Beragama. https://www.uin.ma-lang.ac.id/r/161201/toleransi-dalamberagama.html. Diunduh 3 Agustus 2020, pukul 19.30 WIB.

Suryadi, Ace. dan Budimansyah, Dasim. (2004). Pendidikan Nasional Menuju Masyarakat Indonesia Baru. Bandung: Genesindo.

Suryohadiprojo, Sayidiman. (2016). Budaya Gotong Royong dan Masa Depan Bangsa. Jakarta: Penerbit Kompas Media Nusantara.

Susilana, Rudi. dan Riyana, Cepi. (2008). Media Pembelajaran: Hakikat, Pengembangan, Pemanfaatan, dan Penilaian. Bandung: CV Wacana Prima.

Syarif, Mahmud Bin Asy. (2003). Alquran Bertutur tentang Cinta. Yogyakarta: Cahaya Hikmah.

Thaha, Idris. (2018). Islam dan PDI Perjuangan: Akomodasi Aspirasi Politik Umat. Jakarta: Prenadamedia Grop.

Tim Penyusun. (2016). Materi Pelatihan Guru Implementasi Kurikulum 2013 Tahun 2016. Jakarta: Direktorat PSMP.

Triwiyanto, Teguh. 2019. Gelombang Liberalisme Pendidikan: Mengawal Tata Kelola Pendidikan untuk Rakyat. Jakarta: PT Kompas Media Nusantara.

Ubaid. 2017. Dahsyatnya Ikhlas Bahayanya Riya'. Jakarta: Darul Haq.

Ula, S. Soimatul. (2013). Buku Pintar Teori-teori Manajemen Pendidikan Wahyudi, Amien. 2017. Character Education: Literatur Study Religious Tolerance Character (Prosiding Seminar Bimbingan dan Konseling Tersedia Online di Vol. 1, No. 1, 2017, hlm. 49-56 http://pasca.um.ac.id/conferences-/index.php/snbk ISSN 25799908.

Weruin, Urbanus Ura. (2014). Manusia, Kebudayaan, dan Masyarakat: Konsep Dasar dan Relasi Dialogis Antara Manusia, Kebudayaan, dan Alam. Tangerang: Pustaka Mandiri.

Widodo, Chomsin S. dan Jasmadi. 2008. Panduan Menyusun Bahan Ajar Berbasis Kompetensi. Jakarta: PT Elex Media Komputindo.

Yamin, Moh. (2012). Panduan Manajemen Mutu Pendidikan. Yogyakarta: Diva Press.

Zuchdi, Darmiyati; Ghufron, Anik; Syamsi, Kastam; Masruri, Muhsinatun Siasah. (2013). Pemetaan Immplementasi Pendidikan Karakter di SD, SMP, dan SMA di Yogyakarta. Artikel dalam Jurnal Pendidikan Karakter, Tahun IV, No. 1 Februari 2014. hlm. $1-10$. 